\title{
QARD-AL-HASSAN AS A TOOL FOR POVERTY ALLEVIATION: A CASE STUDY OF THE FAEL KHAIR WAQF PROGRAM IN BANGLADESH
}

\author{
Farah Muneer ${ }^{1}$ and Foyasal Khan ${ }^{2}$ \\ ${ }^{1}$ Institute for Inclusive Finance and Development (InM), Bangladesh, muneerfarah@gmail.com \\ ${ }^{2}$ Department of Economics, International Islamic University Malaysia (IIUM), Malaysia, foyasal.khan@gmail.com
}

\begin{abstract}
The central focus of the Islamic economic system is on socioeconomic justice and the overall welfare of society, especially at the bottom of the pyramid segment. Qard-alHassan, alongside zakat and sadaqah, is one of the instruments for the redistribution of income and wealth from the rich to the poor in Islam. In 2007, Bangladesh was struck by super cyclone SIDR, leaving 3,406 people dead. Moreover, SIDR caused unprecedented damage to homes, crops and livelihoods. The Fael Khair Waqf (FKW) Program came as a response to the urgent need to assist the victims of the cyclone and initiated an interest-free micro-loan (Qard-al-Hassan) scheme to restore the livelihoods of a large segment of the victims and to lift them out of poverty. While investigating the effectiveness of Qard-al-Hassan in poverty reduction, this paper also examines the FKW program as a case study. Analysis was conducted of 1600 households using an independent sample t-test and logistic regression to investigate to what extent the program has been effective in reducing poverty. The findings of the logistic analysis are that the probability of being poor for FKW participants is around 1.46 times lower than for non-participants. Moreover, the Qard-al-Hassan of FKW lowers the cost of borrowing significantly and hence participants can accumulate more assets, which might help them to improve their economic status. Overall, the effectiveness of the program implies that development practitioners and researchers should promote the outreach of Qard-al-Hassan so that the extreme poor can easily avail themselves of the services.
\end{abstract}

Keywords: Qard-al-Hassan; Poverty Alleviation, Fael Khair Waqf (FKW) program; Cost of Basic Needs (CBN) method; Logistic analysis.

JEL Classification: D31; G21; I32.

Article history:

Received : September 16, 2019

Revised : October 8, 2019

Accepted : : December 23, 2019

Available online : December 27, 2019

https://doi.org/10.21098/jimf.v5i4.1100

Acknowledgements: The authors are grateful to the Islamic Development Bank for entrusting InM to evaluate the Fael Khair Waqf program in Bangladesh. The study is based on the data collected during the evaluation period. 


\section{INTRODUCTION}

\subsection{Background}

The inclusive well-being of any society can be improved if economic and social justice for all is ensured in the true sense of the term, which is something the Islamic economic system focuses on centrally. In the Islamic system, individuals can pursue their personal interests within the broader realm of societal interest. That is why morally guided individuals are ready to sacrifice their own personal interests if they are not in line with collective ones. Production, consumption, distribution and redistribution are the basic features of any economic system, which has its own distinct related philosophical views, institutions and instruments. There are a number of social financial institutions and instruments within Islam which centre on the principles of mutual co-operation (al-taawoun), risk-sharing (al-musharakat fi al-makhatir) and social justice (al-adalah al-ijtimayyiah). Among others, zakat, sadqah, waqf and Qard-al-Hassan are some of the classical instruments of Islam that support the creation of a society where wealth is redistributed from the rich few to the many poor people. In this way, Islamic economic instruments can be effective in achieving sustainable development, including the alleviation of all forms of poverty (Iqbal \& Shafiq, 2015; Mohieldin, Iqbal, Rostom, \& Fu, 2011).

Financial inclusion in the form of enhancing access to financing for people of all walks of life is key to ending poverty (Mohieldin et al., 2011). The glorious history of Islamic civilization bears testimony to the fact that Islamic institutions such as zakat, waqf and Qard al-Hassan have played a key role in creating a caring society, in which the basic needs of everyone are met (Zarqa, 1988; Siddiqi, 2004, in Aslam Haneef et al., 2015). The practice of Qard al- Hassan has been encouraged based on the principles of mutual co-operation and brotherhood, with rich people providing loans without charging any interest to low income groups and thus contributing to lessening the gap between rich and poor in society (Mojtahed \& Hassanzadeh, 2009). At present, the Islamic banking system is able to create an enabling environment for the development of poverty alleviation programs based on Qard-al-Hassan and can thus enhance financial inclusion in Bangladesh. For example, micro-credit programs can be offered through Qard-al-Hassan to redistribute income among the community.

Bangladesh is prone to recurrent disasters, especially in the south-western regions of the country. During the past eight years, three cyclones have affected these areas. The most devastating one was SIDR; millions of people were affected in 12 districts $^{1}$, namely Bagerhat, Khulna, Satkhira, Jhalokathi, Pirojpur, Barisal, Patuakhali, Barguna, Bhola, Gopalgonj, Shariatpur and Madaripur. Both physical and non-physical assets were destroyed and sources of livelihood were also affected. In such a situation, people basically coped with their own savings for survival. But livelihood emerged as a major issue immediately after SIDR. The Islamic Development Bank, with grant of US 130 million from an unknown philanthropist, designed a special program for SIDR-affected households, popularly known as the Fael Khair Waqf (FKW) program. Twelve districts severely affected by SIDR were selected for the implementation of the program, with two components - livelihood

1 The eight divisions of Bangladesh are divided into 64 districts (local government administrative units) 
and the construction of shelter-cum-school houses. The program was basically an Islamic finance model based on a microfinance program with interest free loans, or Qard al-Hassan.

In Abhijit et al.'s book Poor Economics, they argue that inadequate understanding of poverty is the main reason for the failure of the majority of anti-poverty policies. To build a world without poverty, researchers should have a willingness to learn from evidence (Banerjee \& Duflo, 2011). The Fael Khair Waqf (FKW) program has brought about an opportunity for us to understand how effective Qard al-Hassan could be as an instrument of poverty alleviation in the form of a field experiment.

\subsection{Objective}

In general, the paper discusses the role of Qard al-Hassan in poverty alleviation. In particular, it aims to observe how FKWP has had an impact on poverty reduction amongst its beneficiaries, SIDR/Aila-affected households. To measure poverty, the study will focus solely on the cost of basic needs (CBN) method. As it is a unidimensional approach, the CBN method relies on only one household indicator, total expenditure, but it is widely used to understand the absolute poverty scenario and to identify the people who are unable to meet their basic human requirements, and thus are living in extreme or life-threatening poverty.

The paper is expected to contribute to the body of knowledge in the experimental area of Islamic economics. Experimental study on the application of Qard al-Hassan in poverty alleviation is new in Bangladesh. To the best of our knowledge, no study has been conducted on this topic in the country. The distinct features of this paper are: i) it deals with a large sample size; ii) it makes a comparison with a separate control group; and iii) it works with a sample that has been trying to cope with severe environmental shock. It also addresses the role of Qard-Al-Hasan not just for poor households, but also extremely vulnerable ones who are trying to cope with the aftermath of a severe disaster which caused catastrophic loss in terms of lives and assets. In this way, the study is unique as it explores areas not yet covered in any experimental studies, and which is the primary motivation for conducting it.

\section{LITERATURE REVIEW}

\subsection{Qard-al-Hassan: Meaning, Definitions and Characteristics}

Qard-al-Hassan consists of two key words: Qard means loan, while Hassan means beautiful. Therefore, the literal meaning of Qard-al-Hassan is 'beautiful loan'. While Abdullah Yusuf Ali (1872-1948) used this meaning in his translation of the Holy Qur'an, Marmaduke Pickthall mentioned two other meanings of Qard-alHassan in his Meanings of the Holy Qur'an: (a) a goodly loan (see, Al-Qur'an, 2: 245; 57:11; 57:18; 73:20), and (b) a kindly loan (see, Al-Qur'an, 5: 12). It is revealed from the verses where Qard-al-Hassan is mentioned that this type of loan is made directly to Allah and not to the recipient. This is probably a reason for mentioning it as a "beautiful loan" (Iqbal \& Shafiq, 2015). Qard-al-Hassan is also mentioned as a 'benevolent loan' (see Izadyar \& Ragnath, 2014; Iqbal \& Shafiq, 2015). Ali (1989, p.100) argues that "a beautiful loan" is a metaphor for spending in the cause of 
Allah. It not only shows a beautiful spirit of self-denial, but also has manifold blessings because Qard al-Hassan is given to Allah, in whose hands are the keys of want or plenty. A person whose goal is to earn the satisfaction of Allah has no reason to turn away from giving Qard-al-Hassan to a deserving candidate. In the case of Qard al-Hassan, the creditor does not expect any return on the principal from this voluntary loan and even does not press the debtor to return it within an exact period of his own free will, although it is a moral obligation for the debtor to return it (Mohieldin et al., 2011). However, the creditor will waive the demand for payment of the principal if the borrower cannot repay it due to economic hardship, despite his/her best efforts and good intentions (Iqbal \& Shafiq, 2015).

A Glossary of Islamic Economic Terms states that Qard al-Hasanah is "An interestfree loan given mainly for welfare purposes. The borrower is only required to pay back the amount borrowed." In a similar fashion, Umer Chapra (2005) defines Qard-al-Hassan as a loan which is returned at the end of an agreed period without any interest of share in the profit of loss of the borrower. Mohammad Nejatullah Siddiqi states that "Qard-al-Hassan [is] lending with no obligation for the borrower more than returning the principal." Similarly, Izadyar and Ragnath (2014) explain that "Qard al-hasan is an interest free loan in which only the return of the capital is required during the term of the loan."

Allah promises multiple returns for Qard-al-Hassan. Unlike zakat and sadaqat, Qard al-Hassan is not a gift, but a loan that has to be repaid. It is an instrument of development to preserve human dignity because only the borrower has the opportunity to determine the term of the loan. Qard al-Hassan is given importance in a number of verses in the Quran $(2: 245 ; 57: 11 \& 18 ; 64: 17)$. The reward for giving Qard al-Hassan is even higher than that for sadaqah (general charity). The reward for sadaqah is only tenfold, whereas it is eighteen fold for Qard al-Hassan, as reported by the Prophet (Mohieldin et al., 2011). Generally, sadaqah is given to a person who is unable to repay it, whereas any noble man can receive Qard al-Hassan during times of hardship and pay it back when times are good and he is wealthy. Therefore, the practice of Qard al-Hassan generates a sense of brotherhood and encourages cooperation. Both parties (receiver and giver) enjoy a similar status. However, a borrower must be cordial with regard to repaying his debt.

Allah promises to remit sins and give a place in heaven to any person who lends to him. Allah says, "If ye establish worship and pay the poor due, and believe in my messengers and support them, and lend unto Allah a kindly loan, surely I shall remit your sins, and surely I shall bring you into gardens underneath which rivers flow" (Al-Quran, 5:12). In another verse, Allah says "Recite, then, of the Qur'an that which is easy for you... and establish worship and pay the poor due and (so) lend unto Allah a goodly loan. Whatsoever good ye send before you far your souls, ye will surely find it with Allah, better and greater in the recompense. And seek forgiveness of Allah. Lo! Allah is Forgiving, Merciful." Lenders do not expect any monetary reward when giving Qard-al-Hassan. Instead they expect rewards from Allah in this world or hereafter for their acts of benevolence (Iqbal \& Shafiq, 2015). 


\subsection{Qard-al-Hassan: A Tool for Poverty Alleviation and Financial and Social Inclusion}

For the purposes of financial inclusion, numerous microcredit institutions are functioning all over the world at formal and informal levels. These institutions are providing small loans to poor people but charging exorbitant interest rates. While there is lack of credible academic evidence on the role of these institutions in poverty alleviation, the suicides of many borrowers in Andhra Pradesh, India have exposed the fragile system of interest-based microcredit programs. In contrast, Qard al-Hassan could be a tool not only for poverty alleviation, but also for financial and social inclusion (Iqbal \& Shafiq, 2015; Aslam Haneef et al., 2015). The poor can have easier access to financial services at a reasonably low cost if Qard al-Hassan, alongside waqf and zakat, are effectively practised by Islamic financial institutions (Aslam Haneef et al., 2015). In particular, Qard al-Hasaan can be extended to support the needs of the poor, the hardcore poor, the regular poor and the vulnerable poor (Aslam Haneef et al, 2015) because these groups are not ready to take funds for investments and they need to meet their immediate basic needs.

Poor people have the opportunity to engage with income-generating economic activities in a dignified and cost-effective manner if they are financed through Qard al-Hassan. This practice generates important social capital because it enhances trust and harmony among all segments of society. Therefore, building a more cooperative and caring society is possible by promoting Qard-al-Hassan (Iqbal \& Shafiq, 2015). For this to happen, its institutionalisation is very important. People can obtain a loan without interest from a Qard-al-Hassan- based institution on the basis of their merit, skills and expertise, and can be engaged with productive activities (Iqbal \& Shafiq, 2015). They will thus be able to integrate and be included in mainstream society by escaping poverty.

The Islamic economic system cannot support any interest-based microfinance institutions, despite their worldwide coverage in terms of financing for the poor, because Islam considers riba (interest) to be exploitative, unjust and repressive, whether the rate is high or low. Hence, it is strictly prohibited (haram). However, the demand for microloans in society is undeniable. In this case, many scholars advocate Qard al-Hassan as a viable option for financing the poor (Iqbal \& Mirakhor, 2013). Islamic financial institutions can develop financial products based on Qard al-Hassan to upgrade the knowledge and skills of recipients (Aslam Haneef et al., 2015). Thus, Qard al-Hassan can be used as an instrument to develop human resources.

Although it is an established practice to lend through Qard-al-Hassan throughout Islamic society, its institutionalisation is a recent phenomenon. Currently, it is formally used as one of the most advanced and suitable tools for microfinance and financial inclusion. In Indonesia, a number of financial products have been developed using Qard-al-Hassan by Islamic microfinance institutions (Aslam Haneef et al, 2015). In addition, the Rural Development Scheme (RDS) of Islami Bank Bangladesh Limited (IBBL) is providing Qard-al-Hassan of up to BDTK 10,000 (approx. 120 USD) for improving water, sanitation and rehabilitating rural poor people in Bangladesh (Farooqi, Qamar \& Chachi, 2017). 
The empirical findings on Qard-al-Hassan will now be presented. Baitul Mal Wat Tamwil (BMT) in Indonesia has a poverty alleviation model based on Qard al-Hassan financing. Widiyanto, Mutamimah and Hendar (2011) studied the effectiveness of the model and found that important figures in society, including Muslim religious leaders and economists, have endorsed the financing model as effective, as it empowers the needy to take part in economic activities. For this, the model has to be developed further. In another empirical work on BMT, Rokhman (2013) argues that its role in the improvement of income, education and business is significant, but not so with regard to access to healthcare. In contrast, a case study of AKHUWAT by Iqbal \& Shafiq (2015) concludes that the contribution of Qard-al-Hassan to social and financial inclusion is not significant because the Qard-al-Hassan instrument has not been institutionalised in Muslim counties. Oyesanyaa and Salako (2019) studied the impact of Qard Al-Hassan in the Al-Hayat Relief Foundation in Nigeria. They found that Al-Hayat had contributed to financial inclusion by improving financial access for deprived Muslim people through the provision of Qard al-Hassan and has empowered Muslim households economically in a sustainable manner, created employment opportunities, and promoted micro-entrepreneurship by way of strengthening the informal sector (Oyesanyaa \& Salako, 2019).

Small business and start-ups can be supported by Qard-al-Hassan. The recipients can repay loans on an installment basis within the agreed period of time. Qard-al-Hassan-based microfinance institutions can only receive a fee in the form of a service charge. Therefore, doing business becomes less expensive compared to other sources of finance (Mansori, Chin, \& Safari, 2015). Social collateral is the basis of Qard al-Hassan practice. Hence, it is a reliable source of funding for economic development because of the lower lending risk and the potential recirculation of funds among the poor (Mohieldin et al., 2011). The social cost of Qard al-Hassan funds is only limited to the opportunity cost of alternative usage of these funds. However, social benefits are extremely high because microfinance institutions (MFIs) can fund at zero cost and thus act as a good catalyst for growth and development. Qard al-Hassan funding can create jobs and generate income for the poor, deprived and unprivileged (Mohieldin et al., 2011).

In contrast, Izadyar \& Ragnath (2014) highlight that Qard-al-Hassan is not a popular mechanism of financial lending because of the lack of participation by institutional investors and high administrative fees. They recommend the institutionalisation of Qard al-Hassan through the Islamic banking system (Izadyar \& Ragnath, 2014); to this end, microfinance institutions can create Qard al-Hassanbased specific funds (Obaidullah \& Khan, 2008).

\subsection{Cyclone SIDR and the Fael Khair Waqf Program (FKWP)}

Currently, Bangladesh ranks as one of the foremost disaster-prone countries in the world. Cyclones, storms, storm surges, floods, erosion etc. are now recurrent phenomena in the coastal area of the country. A study by MoEF shows that a tropical cyclone hits Bangladesh on average ievery three years (MoEF, 2008). Vulnerability in terms of human casualties is so severe in the country that 53 percent of total global deaths due to cyclones occur in Bangladesh, even though only 1 percent 
of the total global cyclones hit the country each year (Ali, 1999). An unnamed Category III cyclone hit in 1970 and killed nearly 500,000 people (Shamsuddoha \& Chowdhury 2007) and Cyclone Gorky, a Category IV storm, struck Bangladesh in 1991, causing an estimated 140,000 fatalities. In 2007, Bangladesh was struck by super cyclone SIDR, leaving 3,406 people dead. SIDR may have been the strongest cyclone to hit the country, but it claimed far fewer lives than the cyclones of 1970 and 1991 because of effective early warning, mobilisation through cyclone shelters and immediate implementation of disaster relief (Paul, 2009). However, although deaths from SIDR numbered in the thousands, damage to homes, crops and livelihoods was extensive and was reportedly worst. SIDR impacted the southwestern coast of Bangladesh, resulting in loss of life and considerable damage in 30 of the 64 districts of the country (InM, 2016). A total of 2.3 million people were affected at various degrees, while 1 million were affected severely. A study by IFRC estimates a total of Tk.115.6 billion worth of damage and loss caused by SIDR, with the share of damage to physical assets being Tk.79.9 billion and the remainder estimated as loss (IFRC, 2013).

The Fael Khair Waqf Program (FKWP) came as a response to the urgent need for assistance from the victims of SIDR. The program was developed when the Islamic Development Bank (IDB) was entrusted with a generous donation of USD 130 million from late King Abdullah. The program was named Fael Khair, meaning anonymous donor, because at the time it was believed the program was financed and supported by an anonymous individual philanthropist who was deeply touched by the colossal damage to property and the sufferings of the affected people. The person remained anonymous until his death, but is now known to have been the former king of Saudi Arabia, the late King Abdullah (InM, 2016). The purpose of the program was to restore the livelihoods of a large segment of the victims of the cyclone and to lift them out of poverty. The program was implemented initially by four NGOs, namely BRAC, the Islamic Bank Foundation (IBF), the Voluntary Organization for Social Development (VOSD) and Muslim Aid Bangladesh (MAB). However, BRAC is currently not operating the program as they chose not to renew the contract after July 2012 (InM, 2016).

The fund was utilized in two key areas: school-cum-cyclone shelters, and a Rehabilitation Program. Out of the total Fael Khair Program (FKP) funds of USD 130 million, USD 110 million was allocated for the construction of several hundred shelters in the coastal belt of Bangladesh, with the remaining USD 20 million allocated as part of the rehabilitation programs (InM, 2016). The major components of these programs were designed with the agriculture and livestock sector and rural non-farm economic activities in mind. To this end, the programs included several components, including i) providing Qard al-Hassan (interestfree benevolent loans) for agricultural inputs (seeds, fertilisers and insecticides) and agricultural machinery (tractors); ii) providing Qard al-Hassan for small business; iii) replacement of livestock (cows, calves and goats); iv) replacement of fishing equipment (boats, nets); and v) various training programs (vocational, motivational, capacity building, etc.) (InM, 2016).

The most prominent feature of FKWP is the interest-free (Qard-al-Hassanbased) microcredit, which is especially designed for those affected by SIDR. Under this arrangement, these poor can borrow from the MFIs operating FKWP without 
any interest or service charge. There are no hidden costs in the loan contract; the borrower only has to return the principle amount of the loan. There is no formal requirement of savings for the arrangement of loan and no membership fee is required to become a member of FKWP (InM, 2016).

\section{METHODOLOGY}

\subsection{Data}

Up to 2015 (the completion year of FKW program) the total number of borrowers was around 0.2 million. From this population, data were collected randomly from 1200 participant (treatment) households who had been given Qard-Al-Hasan. In addition, 400 control households (who not given Qard-Al-Hasan) were selected from eight operating districts. As the study deals with investigating whether QardAl-Hasan has played any role in reducing poverty, both program and control group were employed to make a valid comparison. The treatment (participant) households were selected from 40 villages, and the control households were selected from 20 villages, giving a total of 60 villages.

\subsection{Model Development}

As mentioned earlier, this paper intends to observe how effective FKW has been in reducing poverty among the beneficiaries. Hence, it is necessary to calculate the poverty rates. We have followed the cost of basic needs (CBN) method to calculate these, as it is widely accepted approach, and the most satisfactory for building up a poverty line, while remaining in the spirit of attempting to ensure that the line covers basic needs (World Bank Poverty and Inequality Handbook, 2009). The first step in calculating the poverty rate in this approach is to determine the poverty lines and their elements. While constructing the poverty lines, this paper closely followed the guidelines of the World Bank's Handbook on poverty and inequality.

To investigate the effect of the FKW program on poverty, logistic regression analysis was conducted to examine the association between the poverty status of the households (the dependent variable), i.e. the log of the odds-ratio and the independent variables, such as the program status of households (i.e. whether the household received Qard-Al-Hasan or not), and other socio-economic characteristics. This model was intended to perfectly fit the type of analysis to be conducted, as it examines the association between (categorical or continuous) independent variables and one dichotomous dependent variable, which in this case is being poor or not. When applying the model to our analysis, we followed Wooldridge (2010).

As mentioned above, for the purpose of the analysis the dependent variable is a dichotomous one, namely being poor or not. The interest variable is another dichotomous variable, which relates to whether the household received Qard-AlHasan or not, because this is the key variable through which we can construct a robust relationship between poverty status and program status. Other independent variables were the savings of the household head, land holdings of 
the household head, household size, educational qualifications of the household head, the household head's occupation, and living standards of the household in terms of access to electricity and safe water. We selected these variables as the related literature gives them as strong influences on poverty.

\subsection{Method}

As mentioned above, the CBN method is used for calculating poverty rates. Below we describe how the poverty line was measured and how the decision rules for being poor or non-poor were determined.

\subsubsection{Poverty Lines and their Elements}

A certain year's food, lower and upper poverty lines were determined in this method. The first step was to estimate the food poverty line (FPL), which is the cost of a fixed basket of food that is considered to provide 2,122 kCal per capita per day. The eleven items that constitute this basket are rice, wheat, pulses, milk, oil, red meat, potatoes (including sweet potatoes), other vegetables (leafy and non-leafy), fish (small and large), sugar (jaggery and refined sugar) and fruits (banana). The total value of a fixed food basket will result in food poverty line for a particular year. It is represented by:

$$
F P L_{t}=\sum_{i t} P_{i t} Q_{i}
$$

where

$\mathrm{FPL}=$ the food poverty line

$\mathrm{P} \quad=$ the price of an item in food basket

$\mathrm{Q}=$ the quantity of an item in the food basket

$\mathrm{i}=$ the items (rice, wheat, pulses, milk, oil, red meat, potato, other vegetable, fish, sugar and fruits)

$\mathrm{t} \quad=$ the year.

\subsubsection{Lower and Upper Poverty Lines}

To estimate the lower and upper poverty lines, non-food allowances were calculated. The lower non-food allowance is the median amount spent by individuals on non-food items, when their total consumption equals the food poverty line. On the other hand, the upper non-food allowance is the median amount spent by individuals on non-food items, when their total food consumption equals the food poverty line.

The lower poverty line is estimated by adding the lower non-food allowance to the food poverty line: 
The upper poverty line is the summation of the upper non-food allowance and food poverty line:

Upper Poverty Line=Food Poverty Line+Upper Non Food Allowance

\subsubsection{Measurement of Poverty Using the CBN Method}

The three poverty lines estimated were used to measure the poverty incidences. A household was deemed poor if its annual per capita consumption expenditure was lower than a poverty line, while the intensity of poverty was determined with reference to difference poverty lines. If a household's annual per capita consumption expenditure was at most equal to the upper poverty line and above the lower poverty line, then it was categorized as moderately poor. A household was vulnerably poor if its annual per capita consumption expenditure was below or equal to the lower poverty line, but above the food poverty line. If annual per capita consumption expenditure was at most equal to the food poverty line, a household was deemed to be extremely vulnerable poor. Finally, any household whose annual per capita expenditure was above the upper poverty line was considered non-poor. Table 1 summarises the decision rules and categories.

Table 1.

Poverty Categories

\begin{tabular}{lc}
\hline Decision Rule & Poverty Category \\
\hline Annual Per Capita Consumption Expenditure $\leq$ Food Poverty Line & Extremely Vulnerable Poor \\
\hline $\begin{array}{l}\text { Food Poverty Line <Annual Per Capita Consumption Expenditure } \leq \text { Lower } \\
\text { Poverty Line }\end{array}$ & Vulnerable Poor \\
\hline $\begin{array}{l}\text { Lower Poverty Line <Annual Per Capita Consumption Expenditure } \leq \\
\text { Upper Poverty Line }\end{array}$ & Moderately Poor \\
\hline
\end{tabular}

Source: InM Research Report for IDB (2015)

As mentioned previously, the intention was to conduct logistical analysis to investigate whether Qard-Al-Hasan has had any impact on households in terms of reducing poverty. A logistic regression will model the chance of an outcome (in this case being poor or non-poor) based on individual characteristics, such as receiving Qard-Al-Hasan and other socioeconomic characteristics. Because chance is a ratio, what will actually be modelled is the logarithm of the chance given by:

$$
\log \left(\frac{P}{1-P}\right)=\beta_{0}+\beta_{1} X_{1}+\beta_{2} X_{2}+\ldots+\beta_{k} X_{k}
$$

where $\mathrm{P}$ indicates the probability of an event or outcome (e.g., being poor or non-poor), and $\beta \mathrm{i}$ are the regression coefficients associated with the reference group and the Xi explanatory variables. It is important to mention that in this paper we have only considered households to be poor if they are below the lower food poverty line; i.e., the extremely vulnerable poor and vulnerably poor, with 
the remaining households considered non-poor. In our case, the logistic model would be:

$$
\operatorname{Logit}\left(\mathrm{P}\left(\mathrm{X}_{\mathrm{ij}}\right)\right)=\log \left(\mathrm{P}\left(\mathrm{S}_{\mathrm{ij}}\right) /\left(1-\mathrm{P}\left(\mathrm{S}_{\mathrm{ij}}\right)\right)\right)=\beta_{0}+\beta_{1} \log \left(\mathrm{Y}_{\mathrm{ij}}\right)+\beta_{2} \mathrm{Z}_{\mathrm{ij}}+\varepsilon_{\mathrm{sij}}
$$

where

$\operatorname{Logit}\left(\mathrm{P}\left(\mathrm{X}_{\mathrm{ij}}\right)\right)=\log$ of the odds ratio of poverty status (dummy variable) of household $\mathrm{i}$ in division $\mathrm{j}$

$\mathrm{Y}_{\mathrm{ij}} \quad=$ program status (dummy variable) of household $\mathrm{i}$ in division $\mathrm{j}$

= vector of household's socio-economic characteristics, such as household head's occupation (dummy variable), education, household's access to electricity and tubewells (dummy variables), and household's ownership of land and financial assets.

$\varepsilon_{\mathrm{sij}}=$ nonsystematic error, reflecting, in part, the unmeasured determinants of $X_{i j}$ that vary between households.

\section{RESULTS AND ANALYSIS}

\subsection{Results}

\subsubsection{Incidence of Poverty}

Table 2 shows the percentage of households with respect to each estimated poverty status in the southwestern region of Bangladesh, i.e. eight districts. It can be seen that around 29 percent of households in the sample are extremely poor. These households are basically those below the food poverty line. The vulnerably and moderately poor categories show the intensity of poverty of the households. We consider the vulnerably poor to be those households that are below or equal to the lower poverty line, but above the food poverty line. Table 2 shows that the percentage of vulnerably poor households is 29 percent of the total sample. This means the extremely poor and vulnerably poor constitute almost 60 percent of total households, and is one of the vital characteristics of this region. The region has borne the brunt of from two consecutive cyclones, SIDR and Aila and households have suffered severe losses of assets and income Hence, we observe such a high percentage of extreme and vulnerable poor in the sample.

The moderately poor are those households that lie below the upper poverty line but above the lower poverty line. From the analysis, these households constituted 10 percent of the total sample. The last category is non-poor. The poverty calculation shows that our sample comprised almost 32 percent non-poor households in the eight districts.

In order to consider any impact of the program, it is important to observe the poverty rates by program and control areas. Even though from cross sectional analysis the impact will not show the dynamics, it is worth taking into account any progress made. In Table 2 we have also compared the poverty head-counts of the program area with the control area. 
Table 2.

Percentage of Households with Respect to Poverty Lines (Category)

\begin{tabular}{lcccc}
\hline & Extremely Vulnerable Poor & Vulnerable Poor & Moderately Poor & Non-Poor \\
\hline $\begin{array}{l}\text { Aggregate } \\
(\mathrm{n}=1597)\end{array}$ & 28.87 & 29.30 & 9.58 & 32.25 \\
\hline $\begin{array}{l}\text { Program } \\
(\mathrm{n}=1199)\end{array}$ & 27.20 & 28.61 & 9.58 & 34.61 \\
\hline $\begin{array}{l}\text { Control } \\
(\mathrm{n}=398)\end{array}$ & 34.42 & 31.41 & 9.04 & 25.13 \\
\hline $\begin{array}{l}\text { Difference } \\
\text { derived from } \\
\text { t-test }\end{array}$ & $-7.39^{* *}$ & -2.79 & 0.71 & $9.49^{* * *}$ \\
\hline $\begin{array}{l}\text { Source: Authors' calculation } \\
\text { nat }\end{array}$ & & & &
\end{tabular}

It is shown that the percentage of extremely vulnerable poor households declined by nearly 7 percentage points for the program group compared to the control group, and the t-test also shows that the difference is significant. We have observed the same trend for vulnerably poor households. The percentage of vulnerable poor is 3 percentage points lower for the program group compared to the control group. On the other hand, non-poor households have increased significantly by 9 percentage points for the program area. The percentage of moderately poor is the same for both program and control. One plausible reason for finding more non-poor in the program area could be that these households have higher income, so have managed to leap over the poverty lines.

\subsubsection{Characteristics of Households with respect to Poverty and Program Status} So far we have observed the poverty status of households in the program and control areas of our sample. However, for policy analysis it is very important to know who the poor are. What are their characteristics? What is their expenditure pattern? Do they save? What level of assets do they have? Table 3 shows the average income, expenditure, level of assets and savings for poor households in the program and control areas of our sample, along with some basic household characteristics. 
Table 3.

Characteristics of Households by Poverty Status

\begin{tabular}{lcccccc}
\hline & \multicolumn{3}{c}{ Program (N=1199) } & \multicolumn{3}{c}{ Control (N=398) } \\
\cline { 2 - 7 } & $\begin{array}{c}\text { HH } \\
\text { below } \\
\text { FPL }\end{array}$ & $\begin{array}{c}\text { HH } \\
\text { below } \\
\text { LPL }\end{array}$ & $\begin{array}{c}\text { HH } \\
\text { below } \\
\text { UPL }\end{array}$ & $\begin{array}{c}\text { HH } \\
\text { below } \\
\text { FPL }\end{array}$ & $\begin{array}{c}\text { HH } \\
\text { below } \\
\text { LPL }\end{array}$ & $\begin{array}{c}\text { HH } \\
\text { below } \\
\text { UPL }\end{array}$ \\
\hline Total Income (Taka) & 90.85 & 101.23 & 105.40 & 78.36 & 86.25 & 89.58 \\
\hline Food Expenditure (Taka) & 38.48 & 42.89 & 44.37 & 35.22 & 40.41 & 41.42 \\
\hline Non-food Expenditure (Taka) & 16.56 & 20.20 & 21.36 & 14.91 & 19.20 & 20.24 \\
\hline Total Expenditure (Taka) & 55.04 & 63.09 & 65.73 & 50.13 & 59.61 & 61.66 \\
\hline Female-Headed HH & $5.61 \%$ & $5.42 \%$ & $5.76 \%$ & $11.68 \%$ & $7.63 \%$ & $7.38 \%$ \\
\hline Age of HH Head (Years) & 44.74 & 44.37 & 44.68 & 45.72 & 45.53 & 45.68 \\
\hline Education of HH Head (Years) & 3.93 & 4.06 & 4.10 & 2.79 & 3.17 & 3.37 \\
\hline $\begin{array}{l}\text { HH Head's Primary Occupation } \\
\text { is as Wage Earner }\end{array}$ & $42.68 \%$ & $38.70 \%$ & $38.03 \%$ & $45.26 \%$ & $43.51 \%$ & $42.62 \%$ \\
\hline $\begin{array}{l}\text { HH Head's Primary Occupation } \\
\text { is Self Employment (Agriculture) }\end{array}$ & $14.64 \%$ & $14.91 \%$ & $14.98 \%$ & $10.95 \%$ & $16.41 \%$ & $17.79 \%$ \\
\hline $\begin{array}{l}\text { HH Head's Primary Occupation } \\
\text { is Self-Employment (Non- } \\
\text { agriculture) }\end{array}$ & $33.64 \%$ & $38.86 \%$ & $39.31 \%$ & $27.01 \%$ & $27.10 \%$ & $27.18 \%$ \\
\hline $\begin{array}{l}\text { HH Head has multiple earning } \\
\text { sources }\end{array}$ & $15.89 \%$ & $20.48 \%$ & $21.51 \%$ & $17.52 \%$ & $22.52 \%$ & $24.83 \%$ \\
\hline Total Land (Decimal) & 18.23 & 24.99 & 25.45 & 17.93 & 29.55 & 32.53 \\
\hline $\begin{array}{l}\text { Physical Assets without Land } \\
\text { (Taka) }\end{array}$ & 70.41 & 93.53 & 97.29 & 55.60 & 77.32 & 84.71 \\
\hline Financial Assets (Taka) & 3.02 & 5.98 & 6.95 & 1.75 & 4.78 & 6.79 \\
\hline \begin{tabular}{l} 
Total Assets \\
\hline
\end{tabular} & 357.63 & 467.44 & 490.54 & 316.17 & 481.45 & 521.25 \\
\hline
\end{tabular}

Source: Field survey

The analysis shows that poor households in the control area have lower income, expenditure, physical saving assets (without land) than in the program area, irrespective of their poverty status. We also found that extremely poor households (households below or equal to the food poverty line) have the lowest income, expenditure, assets and savings compared to the other two groups. The differences in these indicators are less significant when comparing the households below the lower poverty line and those below the upper poverty line.

We also observe that the heads of extremely poor households are less educated than those of households living below the lower poverty line and upper poverty line. The average years of education of the household head is approximately 3 years, while for the other two groups it is 4 years. In addition, the heads of these households are mostly wage-earners; For than 40 percent of heads of extremely poor households are wage earners as their primary occupation. Moreover, the heads of extremely poor households have the lowest percentage of multiple earning sources. The analysis shows that only around 15 percent of extremely poor household heads have multiple sources of earning, whereas in the other two groups more than 20 percent of household heads have multiple earning sources. It is important to note that 25 percent of the heads of households living below or equal to the upper poverty line have multiple earning sources in the control areas. 
It should be mentioned that the difference between food and non-food expenditure is higher for the group living below or equal to the food poverty line than for the other two groups. We can therefore say that extremely poor households spend more on food than non-food items. In the program areas, the percentage of female-headed households is consistent with respect to all the poor households, at around 5 percent. However, in the control areas the percentage of female-headed households is highest in the extremely poor category, at around 12 percent. Regarding assets, the extremely poor households have average physical assets (without land) of Tk. 70,000, whereas households living below the lower poverty line and upper poverty line have physical assets worth Tk. 93,000 and Tk. 97,000 respectively. In addition, the extremely poor households have less land accumulation than the other two groups.

The above findings suggest that the poorer the household, the lower the income, expenditure and accumulation of assets. It is also observed that it is wage earners who fall under the poor category, rather than the self-employed. Femaleheaded households and less educated ones are more prone to be poor. Another important finding is that the control group has a higher number of households with lower income, lower assets, fewer educational qualifications of the household head, a lower number of households with multiple earners, and a higher number of wage-earners and female-headed households. This gives an indication that FKW beneficiaries are better off than the households not receiving FKW interest free loans. In the following section, we will check the robustness of this hypothesis through the t-test and logistic regression.

\subsection{Robustness Test}

\subsubsection{Difference in Socio-Economic Characteristics of Program and Control Groups: Independent Sample T-Test}

From the above discussion, we have observed certain characteristics of the poor. But are these characteristics statistically different between the program and control groups? With reference to Table $x$, we have some indication that the program group is better off than the control group in terms of socio-economic characteristics. However, we need to establish whether these results are robust. Table 4 shows the results of the independent sample t-test to observe whether the key characteristics of the poor are significantly different between the two groups. The results suggest that the program group has significantly higher income, higher food and non-food expenditure, and has more educationally qualified household heads and fewer wage earners. The findings indicate that these factors may have some influence on poverty, and hence we find there are significantly fewer poor in the program group. 
Table 4.

T-Test of Socio-Economic Characteristics of Program and Control Groups

\begin{tabular}{lccc}
\hline & $\begin{array}{c}\text { Program } \\
\mathbf{( N = 1 1 9 9 )}\end{array}$ & $\begin{array}{c}\text { Control } \\
\mathbf{( N = 3 9 8 )}\end{array}$ & $\begin{array}{c}\text { Difference in } \\
\text { t-test }\end{array}$ \\
\hline Total Income (Taka in 1000s) & 121.70 & 101.17 & $20.53^{* * *}$ \\
\hline Food Expenditure (Taka in 1000s) & 48.93 & 45.08 & $3.85^{* * *}$ \\
\hline Non-food Expenditure (Taka in 1000s) & 30.29 & 27.24 & $3.05^{* *}$ \\
\hline Education of HH Head (Years) & 4.75 & 3.79 & $.95^{* * *}$ \\
\hline HH Head's Primary Occupation is Wage Earner (\%) & 30.5 & 39.44 & $8.92^{* * *}$ \\
\hline Poor Households (\%) & 65.38 & 74.87 & $9.48^{* * *}$ \\
\hline
\end{tabular}

Source: Field Survey

\subsubsection{Effectiveness of FKW in Reducing Poverty: Logistic Analysis}

In the previous sections we have observed that the program group (the group that received Qard-Al-Hasan) has fewer poor households than the control group (the group not receiving Qard-Al-Hasan) and is better off than the control group in some key socio-economic characteristics. However, the above results do not confirm whether poverty has any effect on these characteristics. In addition, they do not indicate whether FKW has any significant impact on the poverty status of beneficiaries and if so, at what level. Hence, econometric analysis is important to observe how robustly FKW has contributed to reduce the poverty status of the beneficiaries. Furthermore, we tested how well our logistic model fits the data with the Hosmer and Lemeshow chi-square and chi-square model test. We found the Hosmer and Lemeshow chi-square model to be insignificant, which indicates that the estimation fits the data. Moreover, the results of the chi-square test are significant, which indicates that all the independent variables included in the logistic model improve its fitness.

The logistic analysis in Table 5 confirms that the likelihood of the participants of FKW to be poor is around 1.46 times lower than that of the non-participants, with the results significant at the $5 \%$ level. This indicates that program has a positive impact on reducing poverty, as initially (before the commencement of the program) the socioeconomic characteristics were similar for both groups (program and control). If we further analyse the characteristics of the poor, we find that poor households have lower savings, less education, a lower level of land holdings and a higher household size than the non-poor households. Hence, we can argue that poor households are not only deprived of physical capital, but that they are also deprived of human capital. We also found that if the household head is a wage earner, then the probability of that household being poor is 1.43 times higher than for self-employed household heads. We also found that household heads with multiple earning sources had a 1.3 times significantly lower probability of being poor. The logit analysis also shows that households with electricity access and tubewell water access had an almost two times lower probability of being poor than those without access. It is important to mention that as shown in Table 3, that FKW participants are better off than non-participants in terms of the abovementioned indicators, irrespective of their poverty status. This indicates that the program may also have an effective impact on accumulating physical and financial assets and human capital and in achieving a better living standard. 
Table 5.

Impact of FKW on Reducing Poverty (Logistic Regression)

\begin{tabular}{lcc}
\hline VARIABLE & $\begin{array}{c}\text { If HH is below or } \\
\text { equal to the lower } \\
\text { poverty line }\end{array}$ & Standard error \\
\hline FKW participation & $\begin{array}{c}\text { Odds Ratio } \\
\text { HH savings } \\
.6829893^{* *}\end{array}$ & .0961643 \\
HH land holdings & $.9773638^{* * *}$ & .0032585 \\
HH size & $.9964389^{* * *}$ & .000978 \\
Year of education of HH head & $1.864107^{* * *}$ & .0945782 \\
If HH head is wage-earner & $.9615045^{* * *}$ & .0151876 \\
If HH head has multiple earnings sources & $1.439023^{* * *}$ & .2047532 \\
If HH has electricity access & $.7530676^{* *}$ & .1137501 \\
If HH has tubewell access & $.5230643^{* * *}$ & .0800768 \\
Constant & $.4975234^{* * *}$ & .1448416 \\
Hosmer-Lemeshow chi2 & .7568812 & 0.421 \\
Pearson chi2 & $\mathbf{9 . 5 0}$ & $\mathbf{0 . 3 0 1 8}$ (sig. level) \\
\hline Observations & $\mathbf{1 7 0 9 . 2 5}$ & $\mathbf{0 . 0 1 0 6}$ \\
\hline
\end{tabular}

*** $\mathrm{p}<0.01,{ }^{* *} \mathrm{p}<0.05,{ }^{*} \mathrm{p}<0.1$

Source: Field Survey (2015)

\subsection{Analysis}

The above results suggest that the FKW program has had a significant impact on reducing poverty in the disaster-prone areas of Bangladesh. The logit analysis found that Qard-Al-Hasan receivers are 1.46 times less likely to be poor than non-receivers. This is expected, because given the feature of the FKW program of offering interest free loans, it is likely that, without any burden of interest payment on the beneficiaries, the income of the program households would be higher than that of the control households. This higher income enables them to spend more on any items required. It also helps them to move out of poverty. It is important to note that we have also found that FKW program beneficiaries have significantly higher income and expenditure than non-beneficiaries.

Our findings are in line with those of Farooqi et al. (2017) in Bangladesh, Iqbal and Shafiq (2015) in Pakistan, and Effendi (2013) in Indonesia. Farooqi et al. (2017) conducted a study of 700 women in Bangladesh and found a positive and significant influence of the gross monthly income of borrowers. Iqbal and Shafiq (2015) investigated the AKHUWAT program as a case study of Qard-Al-Hasan and found that it had successfully improved the standard of living of its beneficiaries by transforming them into donors. Effendi (2013) conducted qualitative analysis of the role of Islamic microfinance in poverty alleviation, finding that Islamic microfinance was more successful than conventional microfinance in reducing poverty because of its interest-free financing options and more flexible repayment plans.

However, our findings contradict those of Widiyanto et al. (2011), who conducted a study of the business performance of 84 business Qard-Al-Hasan 
receivers and its impact on generating higher income. They found that there was no impact on business performance, as initial Qard-Al-Hasan financing was too low to have an impact on business performance, and hence the impact of financing was invisible. However, they found that business income and profit significantly increased while comparing entrepreneurs who received Qard-Al-Hasan financing for the first time (initial condition) and in the conditions when the research was conducted (second condition). They argued that Qard-Al-Hasan contributed to the greater benefit of society, as the participants were willing to pay zakah and infaq. One of the crucial differences between our study and that of Widiyanto et al. (2011) is the sample size, sample characteristics and methodology. This study compares the findings of Qard-Al-Hasan receivers and non-receivers, not just comparing the before and after situation. Furthermore, our sample consists of 1600 households who basically are very poor and are sitauted in disaster-prone areas. For them, access to small interest free loans will have a greater impact on reducing poverty, as bearing cost of fund can be burdensome on them. On the other hand, Widiyanto et al.'s (2011) study evaluates relatively better-off households who are engaged in business activity and need large loans, which will have a significant impact on their business activity and thus reduce poverty. Therefore, the results of the two studies differ.

Although the findings of this study are similar to many other Islamic microfinance studies, it makes a unique contribution by explaining the role of Qard-Al-Hasan in poverty mitigation in several ways. First, this study deals with a large sample of household data, which creates strong ground for robust results. Second, it investigates the effectiveness of Qard-Al-Hasan on a sample attempting to cope with the aftermath of a severe disaster, as the program itself was instigated as a response to the urgent need for assistance by the victims of the disaster. Therefore, the beneficiaries were already extremely vulnerable, as they had to deal with severe environmental shock. This implies that if the program is proved to have had a positive impact on the livelihood of these households, we can conclude that Qard-Al-Hasan has not only been very effective in improving the situation of just poor households, but has also played an important role in lifting the most extremely vulnerable segment of society from the bottom of the pyramid. This study has made a unique contribution by showing the effectiveness of Qard-Al-Hasan, as it has successfully been proven with robust results that it has played an important role in changing the lives of not only poor, but also the poorest of the poor.

\section{CONCLUSION AND RECOMMENDATION}

\subsection{Conclusion}

This paper has addressed the effectiveness of the FKW program, which is a Qardal-Hassan (interest-free benevolent loan), in reducing the poverty situation of the participants. The results show that the program has had a significant impact on reducing poverty when comparing the poverty headcount between the program and control area. They show that 27 percentage of households are extremely vulnerably poor in the program area, against 34 percentage of households in the control area, with the results statistically significant. The logistic analysis confirms 
that the probability of being poor for FKW participants is around 1.46 times lower than that of non-participants, with the results significant at the $5 \%$ level. This indicates that the program has had a positive impact on reducing poverty, as initially (before the commencement of the program) the socioeconomic characteristics were similar for both groups (program and control). The findings also indicate that the FKW participants are better off than the control households. They have higher income and a greater ability to spend more on food and non-food items. As FKW offers interest-free loans, the cost of borrowing becomes significantly lower and hence people can accumulate more assets, which might help them to improve their economic status after the cyclone. This notion is validated by our results, as we found that program participants had greater financial assets than non-participants. Finally, we can say that FKW, by providing Qard-Al-Hasan, is an effective program in terms of poverty reduction, as it has contributed to higher economic outcomes for the participating households. It has played a vital role in lifting the most extremely vulnerable segment of society up from the bottom of the social pyramid.

\subsection{Recommendation}

Based on the findings, the study suggests the development of certain policies by practitioners, regulators and future researchers. First, considering the effectiveness of Qard-Al-Hasan in poverty reduction, practitioners should increase its outreach. Even traditional microfinance practitioners can develop a Qard-Al-Hasan component along with their traditional credit programs. Second, the findings also show that savings can significantly influence poverty reduction. Based on this, Qard-Al-Hasan can be tied in with small amounts of savings. Accumulated savings over time will not only increase the ability of borrowing households to invest, but will also reduce their dependency on borrowed funds, acting as insurance against future losses for this vulnerable segment. In this way, the default rate can also be minimised. Third, the size of loans under Qard-Al-Hasan is usually small. Given its impact on poverty reduction, these could be increased. Larger loan sizes for enterprising borrowers will lead to sustainable graduation from poverty. Fourth, the third recommendation has important implications for regulators, who should provide incentives to Qard-Al-Hasan providers to offer larger loans. They could set a minimum level for providing a particular number of loans to entrepreneurs. They could also promote the institutionalisation of Qard-Al-Hasan, as it is still informal in nature in its operation. Fifth, the second and third recommendations provide scope for future research for the development of practitioners and academicians. Future research is necessary to develop the savings and large loan components under Qard-Al-Hasan, so that the model can be successfully used for reference and as a framework. 


\section{REFERENCES}

Ali, A. Y. (1989). The Holy Quran: Text, Translation, and Commentary. Maryland: Amana Corporation.

Ali, A. (1999). Climate change impacts and adaptation assessment in Bangladesh, Climate Research, 12, 109-116.

Aslam Haneef, M., Pramanik, A. H., Mohamed, M. O., Muhammad, A. D., \& Amin, F. M. (2015). Integration of Waqf and Islamic microfinance for poverty reduction: Case studies of Malaysia, Indonesia and Bangladesh. The Statistical, Economic and Social Research and Training Centre for Islamic Countries (SESRIC).

Banerjee, A. V. \& Duflo, E. (2011). Poor economics: A radical rethinking of the way to fight global poverty. Public Affairs.

Effendi, J. (2013). The role of Islamic microfinance in poverty alleviation and environmental awareness in Pasuruan, East Java, Indonesia: A comparative study. Universitätsverlag Göttingen.

Farooq, M.O. \& El Ghattis, N. (2015). Qard Hasan, Credit Cards and Islamic Financial Product Structuring: Some Qur'anic and Practical Considerations. Journal of Islamic Financial Studies, 1(1), 1-21.

Farooqi, A. H., Qamar, M. U. R., \& Chachi, A. (2017). Role of Islamic Microfinance Scheme in Poverty Alleviation and Well-Being of Women Implemented by Islami Bank Bangladesh Limited. İslam Ekonomisi ve Finansı Dergisi (IEFD), $3(1), 1-32$.

Haughton, J., \& Khandker, S. R. (2009). Handbook on poverty and inequality. Washington: World Bank.

IFRC (2013), Emergency Appeal Six-Month Consolidated Report - Bangladesh: Tropical Cyclone Mahasen.

Institute for Inclusive Finance and Development (InM) (2016), Impact Assessment Study of the FKW Rehabilitation and Livelihood Program and Implementing NGOs, Final Report prepared for Islamic Development Bank. Dhaka: InM.

Iqbal, Z., \& Shafiq, B. (2015). Islamic finance and the role of Qard-al-Hassan (Benevolent Loans) in enhancing inclusion: a case study of AKHUWAT. ACRN Oxford Journal of Finance and Risk Perspectives, 4(4), 23-40.

Izadyar, A. B., Ragnath, F., \& Özdemir, M. (2014). A New Perspective of Benevolent Loan, Qard Al-Hassan, Using Upfront Payment 'Mesbah Point'. Uluslararası İslam Ekonomisi ve Finansı Araştırmaları Dergisi, 1(1), 199-217.

Mohieldin, M., Iqbal, Z. Rostom, A., \& Fu, X. (2011). The Role of Islamic Finance in Enhancing Financial Inclusion in OIC Countries. Presented at the 8th International Conference on Islamic Economics and Finance. Qatar: Center for Islamic Economic and Finance, Qatar Faculty of Islamic Studies, Qatar Foundation

Mansori, S., Chin, S. K., \& Safari, M. (2015). A shariah perspective review on Islamic microfinance. Asian Social Science, 11(9), 273-280.

MoEF (2008), Bangladesh Climate Change Strategy and Action Plan, Dhaka: Ministry of Environment and Forests, Government of Bangladesh.

Mojtahed, A., \& Hassanzadeh, A. (2009). The Evaluation of Qard-al-Hasan as a Microfinance Approach in Poverty Alleviation Programs, 1-32.

Obaidullah, M and Khan, T (2008), Islamic Microfinance Development: Challenges and Initiative, IRTI-IDB, Jeddah 
Oyesanyaa, O.S. \& Salako, T.A. (2019). A Sharī'Ah Assessment of Al-Qarḍ AlHasan (Ethical Loan) and Its Impact in Al-Hayat Relief Foundation, Ogun State, Nigeria. Journal of Islamic Social Sciences and Humanities, 18, 40-59

Paul, B. K. (2009). Why relatively fewer people died? The case of Bangladesh's Cyclone Sidr. Natural Hazards, 50(2), 289-304.

Rokhman, W. (2013). Baitul Mal Wat Tamwil (BMT) and Poverty Empowerment. Qudus International Journal of Islamic Studies (QIJIS), 1(2): 181-195

Shamsuddoha, M., \& Chowdhury, R. K. (2007). Climate change impact and disaster vulnerabilities in the coastal areas of Bangladesh. COAST Trust, Dhaka.

Widiyanto, Mutamimah \& Hendar (2011), Effectiveness of Qard al-Hasan Financing as a Poverty Alleviation Model, Economic Journal of Emerging Markets, 3(1), 2742

Wooldridge, J. M. (2010). Econometric Analysis of Cross Section and Panel Data. Second edition. Cambridge, Mass.: MIT Press.

Zauroab, N. A., Saada, R. A. J., \& Sawandia, N. (2016). Determinants of Qardhul Hassan financing acceptance in Nigeria. Presented in ISSC 2016 (International Soft Science Conference). Published by Future Academy. www.FutureAcademy. org.uk 